\title{
Grooming behaviors and the translocation of queen mandibular gland pheromone on worker honey bees (Apis mellifera L)
}

\author{
K Naumann \\ Dept of Biological Sciences, Simon Fraser University, Burnaby, BC V5A IS6, Canada
}

(Received 8 March 1991; accepted 17 July 1991)

\begin{abstract}
Summary - Self-grooming resulted in the translocation of synthetic queen mandibular gland pheromone from the mouthparts and head to the abdomen of honey bee workers. The several observed grooming behaviors do not appear to function solely for pheromone translocation. Little if any, pheromone moved passively on the cuticle. This study provides evidence for an active mechanism of pheromone movement on individual social insects, and suggests that these behaviors play a significant role in the queen's communication with her workers.
\end{abstract}

grooming behaviour / queen pheromone / transfer / worker bee / chemical communication

\section{INTRODUCTION}

Self-grooming, a behavior common to all insects, can function to manipulate pollen, remove irritant particulate matter from the body, clean and straighten wings, remove ectoparasites, and spread pheromones of low volatility about the body (Walker and Archer, 1988). Evidence of pheromone translocation by grooming has been reported for the house fly, Musca domestica $\mathrm{L}$ (Dillwith and Blomquist, 1982) and the tsetse fly, Glossina mortisans mortisans Westwood (Langley and Carlson, 1983). Butler (1954) found that honey bee workers could obtain "queen substance" (mandibular gland pheromone) from any part of a queen's body, suggesting that it had been moved backwards from its source glands in the head, but the mode of this movement was not investigated.

The honey bee queen mandibular gland pheromone complex (QMC) elicits a number of responses from other colony members including attraction of workers, inhibition of queen rearing, and attraction of drones during mating (Winston, 1987). In a colony, the queen is usually surrounded by a number of workers, the retinue, which remove pheromone from her body surface (Naumann et al, 1991) before leaving for $\approx 30 \mathrm{~min}$ of intra-nest movement and frequent worker-worker contacts (Seeley, 1979). The function of the retinue and the subsequent worker behaviors are thought to ensure that QMC is quickly transferred from the queen throughout the nest. Evidence of the ef- 
fectiveness of such a system is given by the observation that workers show behaviors associated with queenlessness within as little as $30 \mathrm{~min}$ after queen removal (Seeley, 1979).

The most abundant QMC component, 9-keto-2(E)-decenoic acid, or 9-ODA, is rapidly translocated in substantial amounts to the legs, thorax, and abdomen of retinue workers after contracting a pseudoqueen lure, despite the fact that this pheromone is gathered primarly with the mouthparts (Naumann et al, 1991). The backwards movement may be due to grooming, passive diffusion, or both. Transfer of QMC to the feet and abdomen of retinue workers may increase the rate at which pheromone can be passed onto the other workers, directly through contact, or indirectly via the comb wax. Grooming behaviors of the honey bee have been described in part by Jander (1976), and we have observed a common pattern of grooming associated with queen attendance and the removal of synthetic QMC from lures. In this paper, retinue worker grooming and experiments designed to investigate the importance of such grooming in the translocation of QMC on workers are described.

\section{MATERIALS AND METHODS}

\section{The grooming behavior of retinue bees}

Artificial-queen lures were created by topically applying, to freshly killed workers $11 \mu \mathrm{l}$ of methanol, $\mathrm{MeOH}$, containing synthetic QMC (250 $\mathrm{ng}$ 9-ODA, $150 \mathrm{ng}$ 9-hydroxy-2(E)-decenoic acid $(71 \%$ R-(-), 29\% S-(+)), 13 ng methyl 4hydroxybenzoate, and $1.5 \mathrm{ng}$ 4-hydroxy-3methoxyphenylethanol (Slessor et al, 1988), and $8 \mathrm{ng}$ of $\left[{ }^{3} \mathrm{H}\right]-9-O D A$ (Webster and Prestwich, 1988 (activity $=450000$ disintegrations/ $\mathrm{min})$. This quantity of $\mathrm{QMC}$ is approximately the mean amount found on the body surface of mat- ed queens (Naumann et al, 1991) and $\approx 10^{-3}$ the mean amount found in the mandibular glands of a mated queen (Slessor et al, 1990). Dead workers were used because they present a surface for pheromone acquisition that is most like that of a queen. Queens themselves are not used for lures because foreign workers may greet them with aggression and behaviors not normally associated with the retinue. After 2-3 min, these lures were placed into Petri dishes with 15 workers which had been removed from their host colony at least $1 \mathrm{~h}$ previously. This number of workers is sufficient to yield retinue behavior. Interactions between workers and lures, and subsequent worker behaviors, including self-grooming, were videotaped using a Panasonic VW-CD110 color camera, an AG-1950 video cassette recorder, and a CT-1330MC color video monitor (Matsushita Electric Industrial Co Inc, Fujisawa, Kanagawa, Japan). Recordings were analyzed for time between the beginning of lure contact and first occurrence of grooming behaviors, and/or probability and frequency of occurrence of grooming behaviors in the next 60-90 s. To test whether or not observed grooming behaviors were exclusive to pheromone transfer, and to control for the effect of $\mathrm{MeOH}$ on worker behaviors, workers from the same host colony were also observed after contacts with dead bees treated with $\mathrm{MeOH}$, or with untreated bees.

\section{Grooming behaviors and pheromone translocation}

Lures treated with synthetic QMC containing $\left[{ }^{3} \mathrm{H}\right]-9-O D A$ were placed into Petri dishes containing 15 workers. After making sustained ( $>5$ s) contacts with the lure, individuals which had also subsequently or concurrently groomed their mouthparts, thoraces, and abdomens, for any length of time, were removed. An equal number ( $n=13$ ) of lure-contacting workers were pulled from the dishes before any grooming had occured. Removed workers were quickly dissected to yield mouthparts, head, legs, thorax, abdominal integument, and abdominal contents. The thorax and abdomen were first frozen on dry ice to allow complete removal of the alimentary tract and its contents from the abdomen. To remove contaminating radio-label, all dissecting imple- 
ments were twice washed with $\mathrm{MeOH}$ between operations. The body parts were then immersed in $10 \mathrm{ml}$ of BCS biodegradable counting scintillant (Amersham Canada Ltd, Oakville, Ont). After $24 \mathrm{~h}$, the samples were separately analyzed for radio-label content with a Beckmann LS 5801 liquid scintillation counter (Irvine, CA).

\section{Interfering with grooming}

In order to interfere with grooming patterns, all legs of 2 workers were secured to the bottom of plastic Petri dishes with Duco ${ }^{\mathbb{C}}$ cement (Devcon Corp, Wood Dale, IL), 13 nestmates were then introduced, and the dishes of bees left undisturbed, with a source of sugar syrup for at least $1 \mathrm{~h}$. Lures treated with synthetic QMC containing $\left[{ }^{3} \mathrm{H}\right]-9-O D A$ were then introduced to the dishes by presenting them directly to the restrained workers. The unrestrained workers were free to make contact with the lures. After 2-4 min, the glued bees and several of the unrestrained workers which had made contact with the lure were removed, killed by freezing with dry ice, and dissected to yield mouthparts, head, front legs, middle legs, hind legs, thorax, and abdomen. Antennae were also dissected from some individuals. The abdomens were washed with 6 consecutive rinses of $100 \mu \mathrm{l}$ of $\mathrm{MeOH}$ to collect the 9-ODA from the surface. All of the body parts and the $\mathrm{MeOH}$ wash were then analyzed for [3H]-9-ODA content as described above. Fourteen glued bees and 10 free running bees were analyzed.

Passive movement of 9-ODA was investigated by topically applying $1 \mu \mathrm{l}$ of the synthetic pheromone solution to the heads of freshlykilled workers. After $2 \mathrm{~min}$, head, thorax, and abdomen of each worker $(n=25)$ were removed and individually analyzed for radio-label content by scintillation counter.

Data were analyzed by t-tests using Minitabß data analysis software (State College, PA). Proportional data were arcsin-square root transformed. The analyses are only for workers which had gathered amounts of radiolabel at least 2 standard deviations greater than average background levels; workers containing only background counts can show false and ambiguous patterns of radio-label distribution.

\section{RESULTS}

\section{Grooming behavior of retinue bees}

The grooming behaviors most commonly observed for workers in, or just leaving, the retinue were as follows:

Antennal cleaning. This was the most frequent grooming behavior of the retinue bees. They typically scraped one antenna at a time by stroking it distad with the ipsilateral foreleg cleaner.

Head cleaning. The rest of the head was also occasionally swiped by downward movements of a foreleg.

Mouthpart grooming. The mouthparts were also frequently cleaned by individuals that had made contact with a lure or queen with their proboscis. Usually, both foretarsi would simultaneously scrape the unfolded proboscis, in a direction away from the head, often 3-4 times consecutively.

Thorax and abdomen grooming. Less frequently, retinue workers would step back from the lure to groom legs, thorax, and abdomen, ie forelegs rubbed middle legs and thorax, middle legs contacted hind legs, thorax, and/or abdomen. Some individuals stroked the hing legs several times along the sides of the abdomen. Stroking of the legs against each other, the thorax, or the abdomen occurred more commonly when individuals had contacted a lure with their legs, or after they had scraped their mouthparts several times with their forelegs. The workers which had visited the synthetic QMC-treated lures had all made mouthpart (licking) contact with a lure. Naumann et al (1991) showed that such workers gather much more QMC than workers making only antennal contact.

The data in table I show there was a greater tendency for bees that visited lures containing synthetic pheromone or $\mathrm{MeOH}$ 


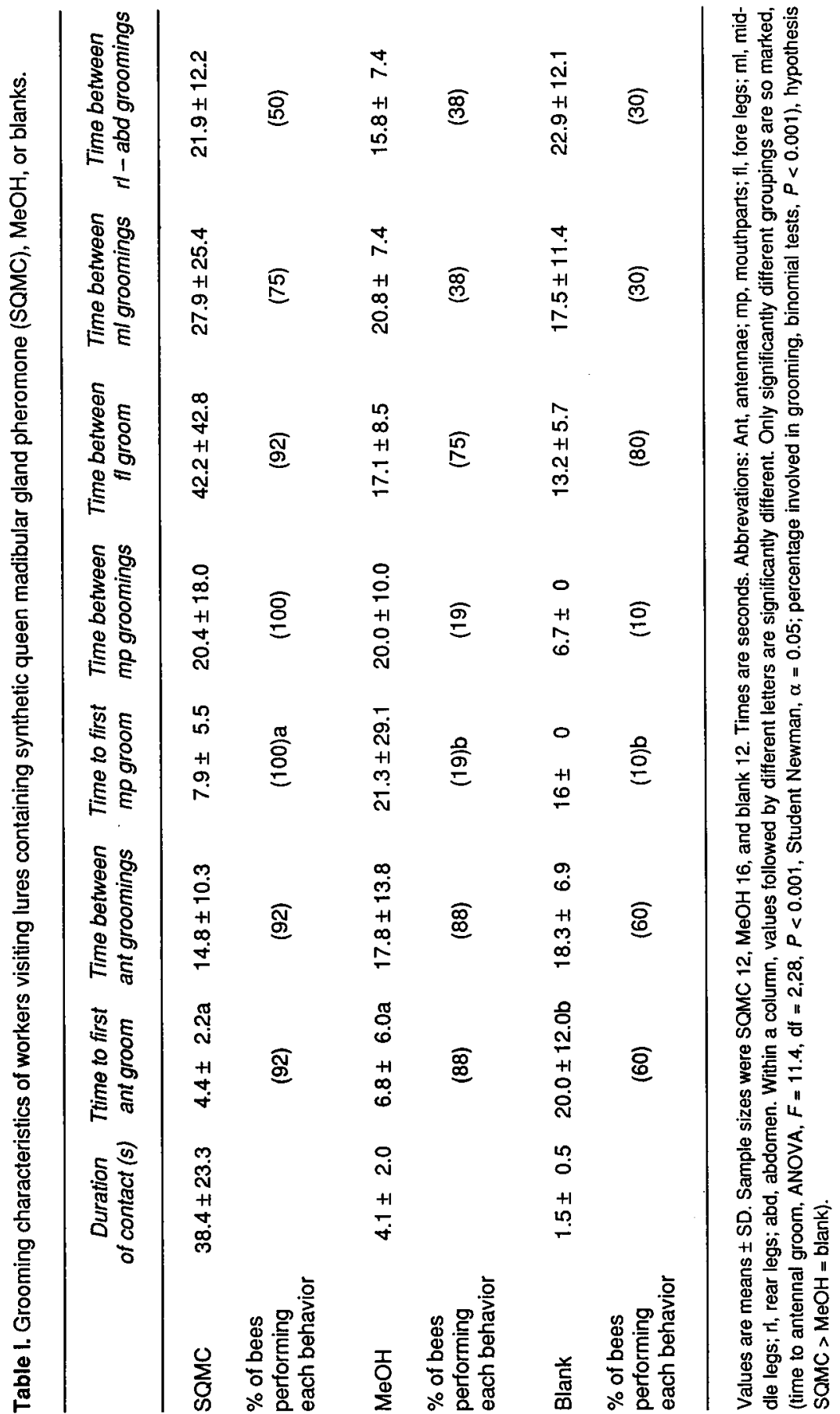


to perform grooming behaviors (percentage performing each behavior) than those visiting the blank controls. However, there was little difference in the types of grooming behaviors observed between individuals visiting lure, ie once an individual was grooming, frequencies and times to initiation of individual movements were similar, regardless of the type of lure contacted. An exception was contact with a synthetic QMC source, which released a more rapid initiation of mouthpart grooming, than contact with either type of control lure.

\section{Grooming behaviors and pheromone translocation}

Grooming and non-grooming workers gathered similar total amounts of radiolabel $(40.2 \pm 16.1 \mathrm{pg}$ and $37.8 \pm 12.1 \mathrm{pg}$ respectively; $t$-test, $t=-0.11$, df $=24, P=$ 0.91 ), and carried similar amounts externally $(21.9 \pm 9.4$ vs $26.5 \pm 8.7 \mathrm{pg} ; t=0.37$, $\mathrm{df}=24, P=0.72$ ). However, the proportion of the externally-carried total that was found on the mouthparts was significantly greater for the non-grooming workers (fig $1 ; t=4.22$, df $=24, P=0.0006$ ), and that on the abdomen was significantly less $(t=-3.98$, df $=24, P=0.0008)$. There were no significant differences for the relative amounts on other body parts; however, the non-grooming workers showed a trend towards carrying relatively more material on their heads $(t=2.06, \mathrm{df}=24, P=$ $0.051)$.

\section{Interfering with grooming}

Workers with legs fixed to the substrate took up tritiated pheromone from a dead bee lure. However, their contacts were not as prolonged as those of free running bees, and usually did not involve as much proboscis contact. As a result, free running bees gathered greater amounts of $\left[{ }^{3} \mathrm{H}\right]-9$ ODA (203 $\pm 63 \mathrm{pg}$ vs $44 \pm 10 \mathrm{pg}(\overline{\mathrm{X}} \pm \mathrm{SE})$; $t$-test, $t=2.51, P=0.033$ ) (untreated controls yieided a background value of 0.2 $\mathrm{pg}$ ), and swallowed substantially more (abdomen counts; $148 \pm 54 \mathrm{pg}$ vs $3 \pm 1 \mathrm{pg}$ ). If only the amounts on the body surface are considered, then both types of bees gathered similar amounts $(65 \pm 16 \mathrm{pg}$ vs $41 \pm$ $10 \mathrm{pg} ; t=1.27, P=0.22$ ), but the pattern of [ $\left.{ }^{3} \mathrm{H}\right]-9-O D A$ distribution on the body was different (fig 2). The proportion of the total recovered quantity of externally carried $\left[{ }^{3} \mathrm{H}\right]-9-O D A$ that was found on the head was significantly less for the free running

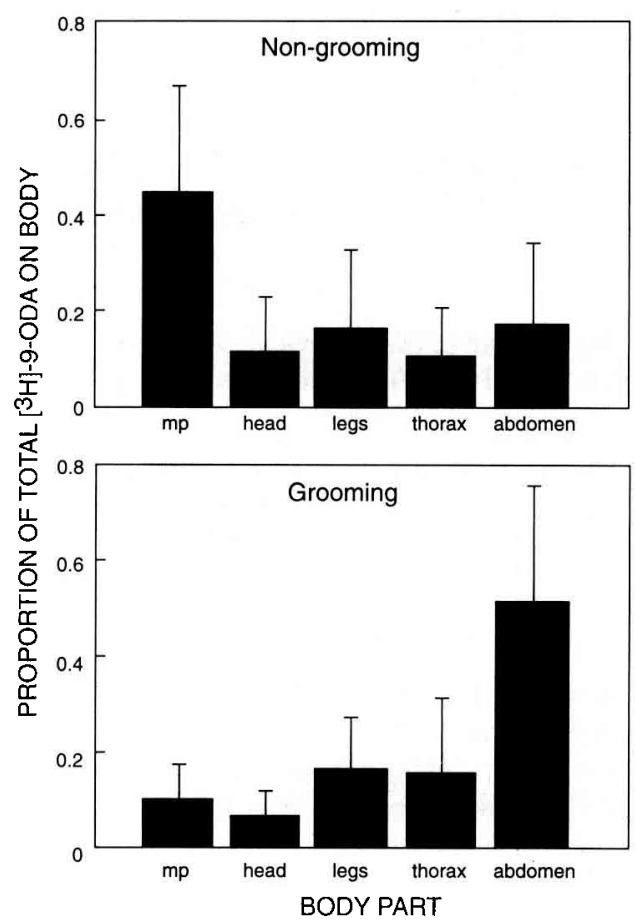

Fig 1. Mean $( \pm S D)$ relative proportions of radio-label $\left.\left({ }^{3} \mathrm{H}\right]-9-O D A\right)$ on different body parts of self-groomed (mouthparts, thorax, and abdomen) and non-groomed workers, after contact with a pheromone lure. $\mathrm{mp}=$ mouthparts. 


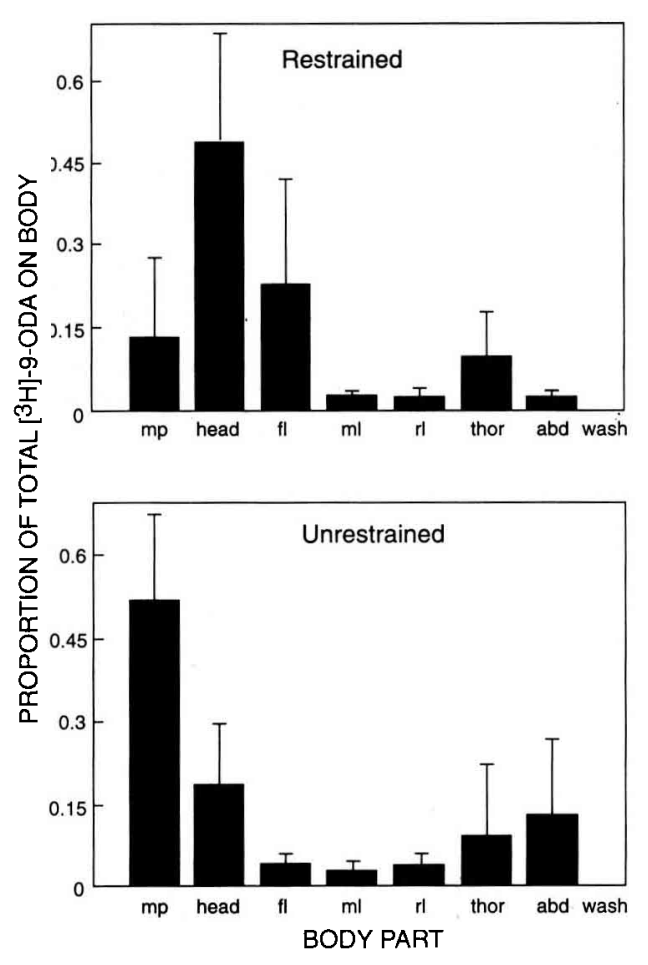

Fig 2. Mean $( \pm S D)$ relative proportions of radiolabel $\left(\left[{ }^{3} \mathrm{H}\right]-9-O D A\right)$ on different body parts of workers which had legs fastened to substrate (restrained), or workers free to move. Radiolabel was gathered by the workers from a lure. mp, mouthparts; fl, front legs; ml, middle legs; $\mathrm{rl}$, rear legs; thor, thorax; abd wash, $\mathrm{MeOH}$ wash of abdomen.

workers $(t=4.0, P=0.0007)$. The proportion of the total found on the forelegs of the free running workers was also significantly less $(t=2.91, P=0.012)$, but the proportion of the total that was on the abdomen, $i e$, in the $\mathrm{MeOH}$ wash, was significantly higher ( $t=-2.69, P=0.025)$. Restrained workers had significantly greater mean amounts of tritiated 9-ODA on their antennae than free running bees $(2.5 \pm 0.9$ pg vs $0.35 \pm 0.05 \mathrm{pg} ; n=11,4, t=-2.43$, $P=0.036)$.
There was no detectable movement of $\left[{ }^{3} \mathrm{H}\right]-9-O D A$ from the head to the abdomen of dead workers in $2 \mathrm{~min} ; 100 \%$ of the recovered $\left[{ }^{3} \mathrm{H}\right]-9-$ ODA being detected on the heads.

\section{DISCUSSION AND CONCLUSION}

Backwards translocation of queen mandibular gland pheromone on worker honey bees occurred, at least in part, as a result of grooming. Butler et al (1974) reported that tritiated 9-ODA applied to the thoraces of workers was translocated to the head and abdomen. However, their 9-ODA was tritiated $\alpha$ to the 9-keto carbon, a position allowing for high lability, and the resulting non-specific tritium exchange with tissue material precluded meaningful interpretation of their results. Also, their results could not be used to deduce whether the route of translocation was internal or external. Individuals that lick a pheromone source swallow some of the material, thus moving it rapidly backwards (Naumann et al, 1991).

The grooming movements observed in this study do not appear to be unique to pheromone transfer. Movements involving the forelegs were the same as those in Jander's (1976) description of self cleaning and pollen manipulation, and behaviors of workers visiting pheromone-lures were not qualitatively different from those visiting $\mathrm{MeOH}$-treated ones. The spreading of pheromone over the body as a result of grooming is somewhat unusual in that grooming is usually undertaken to remove materials from the body. The persistent cleaning of the antennae by retinue bees, which removes 9-ODA, probably serves to keep chemo-receptor sites clear, and grooming of the proboscis may similarly remove materials from an area with chemosensory cells. The free running workers in the second part of this study, and those of 
Naumann et al (1991), showed almost no 9-ODA on their antennae, suggesting that normally the antennae are rapidly and effectively cleaned after contact with a 9ODA source. Contact with $\mathrm{MeOH}$ lures also led rapidly to antennal grooming, and even some workers contacting blank dead bee lures frequently cleaned their antennae. However, workers that had visited pheromone treated lures were more likely to lick the lures and to clean their mouthparts afterwards. Similarly there was no evidence that leg-abdomen contacts were used specifically to translocate pheromone since only some lure-visiting individuals performed such activities. The grooming of the legs, thorax, and abdomen may simply be the self cleaning behaviors of individuals that find themselves carrying an oily substance; even such incidental grooming can facilitate the spread of 9-ODA over the bodies of workers.

Little of the pheromone spread over workers can be attributed to a tendency for 9-ODA to spread passively over the body, although Lewis (1962) demonstrated that oils can, in this way, spread rapidly over the integument of living, active insects. However, occasional bumping by the free running bees, together with some passive translocation on the immobilized but struggling bees, may have deposited some of the [3H]-9-ODA which was recovered from the abdominal surfaces of the bound workers.

The backwards spread of pheromone on the body may aid in transfer to other individuals by increasing the effective body surface area from which other workers can gather QMC, or via comb contact with a greater area of cuticle contaminated with pheromone. Naumann et al (1991) demonstrated that retinue workers leave 9-ODA on the wax of the comb, and that other workers can collect it from there. The dispersal of 9-ODA over the body surface of a bee may also serve to increase the rate at which it is internalized and removed from circulation in the nest. The 2 processes acting in combination could operate to ensure that the queen's signal is both rapidly transferred through the nest, and nonpersistent.

This study has provided the first evidence in a social species for a mechanism of contact pheromone movement on an individual. Other eusocial species may utilize similar pheromone dispersal systems. As such, grooming behaviors which serve to translocate queen-produced pheromones may play a significant role in the queen's communication with her workers.

\section{ACKNOWLEDGMENTS}

I am grateful to to SN Graham, SA Hope, PH Laflamme, GD Prestwich, FX Webster and S Seward for their assistance with this project. Phero Tech Inc of Delta, BC formulated and supplied some of the pheromone components. This study was supported by an NSERC Postgraduate Scholarship and a BC Science Council GREAT Award (to KN), grants from the HR Wright Institute, NSERC operating grants A3785 and A7774, strategic grant G0985, and an AGAR grant from the BC Science Council (to ML Winston and KN Slessor). Helpful comments on this manuscript were provided by ML Winston, KN Slessor and RC Ydenberg.

Résumé - Comportements de nettoyage, et passage de la phéromone de glandes mandibulaires de reine sur les ouvrières de l'abeille (Apis mellifera L). Cette étude traite du passage, sur les ouvrières, du complexe phéromonal de la grande mandibulaire de la reine (QMC). Ce complexe QMC est acquis par les ouvrières lorsqu'elles réalisent le comportement de cour, et ensuite elles le dispersent à travers la colonie. Les composants de la phéromone peuvent être retrouvés 
sur la plupart des régions du corps des ouvrières, quelques secondes après le contact avec la reine. On a analysé la fréquence et la probabilité d'apparition des comportements de nettoyage des ouvrières, pendant et après un contact avec des abeilles fraîchement tuées qui étaient traitées avec un mélange synthétique de QMC contenant un composant marqué au tritium (9-ODA), ou du méthanol, ou sans aucun traitement. Les ouvrières qui avaient visité les leurres contenant du QMC ou du méthanol, ont eu une plus grande tendance à réaliser des comportements de nettoyage, que celles qui avaient visité des leurres contrôles. Cependant, il y a eu peu de différences dans les types de comportement de nettoyage observés entre les individus visitant différents leurres (tableau I).

Des ouvrières qui se nettoient ellesmêmes après avoir visité une source de QMC tritié, ont montré une proportion inférieure de marquage total sur leurs pièces buccales, à celle des abeilles qui ne se sont pas nettoyées, et une proportion supérieure sur leur abdomen (fig 1).

Quand des ouvrières visitant des leurres ont été empêchées de se nettoyer par fixation de leurs pattes sur le support, elles ont significativement plus de marquage sur leurs têtes et leurs pattes antérieures, et moins sur leurs abdomens, que des ouvrières libres de se déplacer (fig 2). Du QMC tritié, appliqué sur la tête d'abeilles ouvrières mortes, ne migre pas passivement sur leurs corps.

Ces résultats démontrent qu'un mécanisme actif de transport de la phéromone royale vers l'arrière existe chez les ouvrières, mais qu'il ne dépend pas uniquement du comportement de nettoyage. La dispersion de la phéromone sur le corps peut faciliter le transfert aux autres individus, en augmentant la surface efficace à partir de laquelle d'autres ouvrières peuvent acqué- rir du QMC. Cette dispersion sur le corps peut également servir à augmenter la quantité de QMC qui passe dans le corps des individus, et qui est donc enlevée de la circulation dans la colonie.

Comportement de nettoyage / phéromone royale / transfert / ouvrière / communication chimique

\section{Zusammenfassung - Putzverhalten} und Verteilung des MandibeldrüsenPheromons der Königin aut die Arbeitsbienen. In dieser Studie wurde die Übertragung des Komplexes des Mandibulardrüsen-Pheromons der Königin (QMC, 'Weiselstoff') auf die Arbeitsbienen untersucht. Der QMC wird durch die Arbeiterinnen des Hofstaates von der Königin abgenommen und dann durch das Nest verteilt. Pheromon-Komponenten können innerhalb von Sekunden nach dem Kontakt mit der Königin an den meisten Körperstellen der Arbeiterinnen nachgewiesen werden. Es wurde das spezifische Selbstputzverhalten der Arbeiterinnen während und nach dem Kontakt mit frisch getöteten Bienen, die mit synthetischem, mit Tritiummarkierten QMC-Komponenten (9-ODA) oder mit MeOH imprägniert waren oder die unbehandelt blieben, sowohl nach seiner Häufigkeit wie nach der Wahrscheinlichkeit des Auftretens analysiert. Es bestand eine größere Tendenz zur Ausführung des Putzverhaltens bei Arbeiterinnen, die mit QMC oder $\mathrm{MeOH}$ imprägnierte Köder besucht hatten, als bei solchen nach dem Besuch blanker Kontrollen; zwischen den Tieren, die verschiedene Typen der Köder besucht hatten, bestand jedoch nur ein geringer Unterschied in der Art des Putzverhaltens (Tabelle I). Arbeiterinnen, die sich nach dem Besuch eines Tritium-markierten QMC geputzt hatten, zeigten an ihren Mundwerkzeugen einen geringeren Anteil des gesamten aufgenommenen radioakti- 
ven Materials, und einen größeren Anteil am Hinterleib, als Bienen, die sich nicht geputzt hatten (Abb 1). Wurden Bienen nach Besuch des Köders durch Fixierung der Biene an der Unterlage am Putzen gehindert, so konnte an Kopf und Vorderbeinen signifikant mehr und am Hinterleib weniger radioaktives Material nachgewiesen werden als bei frei laufenden Bienen (Abb 2). Tritium-markierter $Q M C$, aufgebracht auf die Köpfe toter Arbeiterinnen, verteilte sich nicht in meßbaren Mengen passiv über den Körper. Diese Ergebnisse liefern den Beweis für einen aktiven Mechanismus des Transports des KöniginnenPheromons an den einzelnen Arbeitsbienen nach hinten. Gleichzeitig erscheint es als wahrscheinlich, daß das dafür verantwortliche Putzverhalten nicht ausschließlich dem Pheromon-Transport dient. Die Verteilung des Pheromons über die Körperoberfläche kann die Übertragung auf andere Bienen fördern, indem dadurch die wirksame Oberfläche vergrößert wird, von der QMC an andere Bienen übertragen wird; durch die Verteilung über die Körperoberfläche kann aber auch die Rate von QMC erhöht werden, der von den Bienen aufgenommen und damit aus dem Volkskreislauf entfernt wird.

Putzverhalten / Königin-Pheromon / Transport / Arbeitsbiene / chemische Verständigung

\section{REFERENCES}

Butler CG (1954) The method and importance of the recognition of a colony of honeybees (A mellifera) of the presence of its queen. Trans $R$ Entomol Soc Lond 105, 11-29
Butler CG, Callow RK, Greenway AR, Simpson $J$ (1974) Movement of the pheromone, 9oxodec-2-enoic acid, applied to the body surface of honey bees (Apis mellifera). Entomol Exp App/ 17, 112-116

Dillwith JW, Blomquist GJ (1982) Site of sex pheromone biosynthesis in the female housefly, Musca domestica L. Experientia $38,471-473$

Jander R (1976 Grooming and pollen manipulation in bees (Apoidea): the nature and evolution of movements involving the foreleg. Physiol Entomol 1, 179-194

Langley PA, Carlson DA (1983) Biosynthesis of contact sex pheromone in the female tsetse fly, Glossina morsitans morsitans Westwood. $J$ Insect Physiol 29, 825-831

Lewis CT (1962) Diffusion of oil films over insects. Nature 193, 904

Naumann K, Winston ML, Slessor KN, Prestwich GD, Webster FX (1991) The production and transfer of honey bee (Apis mellifera $L$ ) queen mandibular gland pheromone. Behav Ecol Sociobiol (in press)

Seeley TD (1979) Queen substance dispersal by messenger workers in honeybee colonies. Behav Ecol Sociobiol 5, 391-415

Slessor KN, Kaminski LA, King GGS, Borden $\mathrm{JH}$, Winston ML (1988) Semiochemical basis of the retinue response to queen honey bees. Nature 332, 354-356

Slessor KN, Kaminski LA, King GGS, Winston ML (1990) Semiochemicals of the honey bee queen mandibular gland. $J$ Chem Ecol 16, 851-860

Walker ED, Archer WE (1988) Sequential organization of grooming behaviors of the mosquito, Aedes triseriatus. J Insect Behav 1, 97-109

Webster FX, Prestwich GD (1988) Synthesis of carrier-free tritium-labelled queen bee pheromone. J Chem Ecol 14, 957-962

Winston ML (1987) The Biology of the Honey Bee. Harvard University Press, Cambridge, MA 